\title{
角錐-角筒ソケット接合の圧縮耐力 \\ COMPRESSIVE STRENGTH OF HOLLOW PYRAMID CONNECTOR ON SQUARE TUBE
}

\author{
桑 村 仁*, 伊 藤 拓 海** \\ Hitoshi KUWAMURA and Takumi ITO
}

\begin{abstract}
Compressive strength of a steel hollow pyramid placed onto the open mouth of a steel square tube, which is simply named the steel pyramid-to-tube socket connection, was experimentally investigated. Thirteen specimens were tested with various conditions such as welded or metal-touched between the elements, free or restraint edge of the tube, full-web or open-web of the pyramid, entirely uniform compression or local compression of loading, and normal friction or reduced friction. The ultimate behavior, and consequently, the compressive strength as well as the stiffness of the connection were largely affected by these conditions. The analytical resolution about the effects is not available at present. However, the socket connection with the ordinary condition that the pyramid is welded to the tube and to the lid plate, provides sufficient stiffness and strength for practical use.
\end{abstract}

Keywords : Steel socket connection, Folded plate, Compressive strength, Hollow pyramid, Square tube 鋼製ソケット接合, 折板構造, 圧縮耐力, 中空角錐, 角形鋼管

\section{1.はじめに}

今まで, 円錐-円筒ソケット接合と称される接合形式の構造力学 的性能が研究されてきた ${ }^{1,2), 3)}$ 。これは中空の円錐を円形鋼管には め込むことによって閉断面材の接合を簡単にするとともに，両者を 溶接しないでメタルタッチとすれば全方向ピンの接合部を実現でき るというものである。シェルとしてのメンブレン効果を引き出すこ とによって, 薄肉であっても非常に高い強度と剛性が発揮できるこ とが実験的および解析的に実証されている。さて，このソケット形 式は他の閉断面材にも応用が可能である。本論は角形鋼管に中空の 角錐をはめ込んだ角錐一角筒ソケット接合の性能について検討した ものである。この接合形式については既に実験に基づく調査 ${ }^{4), 5), 6)}$ が行われており，本論はそれを取りまとめたものである。

この角錐-角筒ソケット接合は図 1 のような接合部分, すなわち 角形鋼管が使われる柱一梁接合部，柱脚，トラス支承，鋼管継手な どに適用が想定される。これらの圧縮材や曲げ圧縮材にこのソケッ 卜接合を適用するには, それら断面力に応じて, 接合部の剛性, 弾 性限耐力, 最大耐力, 終局状態とそこに到るまでの鞁性などの諸性 能が設計に必要となる訳であるが，その性能が明らかにされていな いため，まだ実用化されてはいない。

解析的な観点からは，円錐-円筒ソケット接合が曲板構造 (shell) として扱われたのに対して ${ }^{11}$ ，角錐一角筒ソケット接合は折板構造 (folded plate) となり, その解析的扱いは異質なものとなる。折板

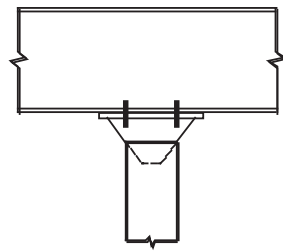

(a) 柱-梁接合

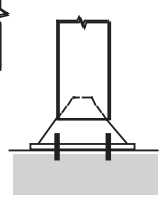

(b) 柱脚

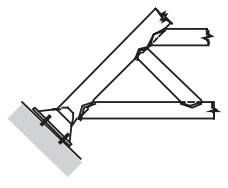

(c) トラス支承

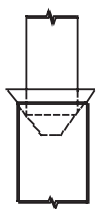

(d) 鋼管継手
図1角錐を角形鋼管にはめ込んだ接合構法の例

構造は構造力学の中で比較的マイナーな分野で, シェルや平板に比 べて研究は少ない。折板の弾性応力解析については, いくつかの名 著を挙げることができる ${ }^{7)-10)}$ 。そこでは, 平板の古典理論に基づき, 釣合と適合の条件を単純化した構造力学的方法, 応力関数による方 法, 選点法など, いくつかの応力解析手法が示されている。折板構

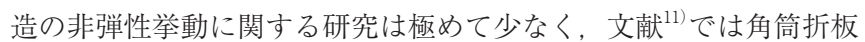
の破壊線理論による塑性解析法が示されている。以上の研究はいず れも面的な等分布荷重を受ける場合に限られている。これに対して, 角錐一角筒ソケット接合では角錐と角筒の接触部で線荷重あるいは 局所的な集中荷重が作用することになり，このような荷重条件に対 する理論的研究は行われていない。この問題は有限要素解析などの 数值解析に頼らざるを得ない状況にあると思われる。したがって,
* 東京大学大学院工学系研究科建築学専攻 教授 $\cdot$ Ph. D.

** 東京大学大学院工学系研究科建築学専攻 助教・博士 (工学)
Prof., Dept. of Architecture, School of Engineering, The University of Tokyo, Ph. D.

Assistant Prof., Dept. of Architecture, School of Engineering, The University of Tokyo, Dr. Eng. 
この角錐-角筒ソケット接合の挙動を理論的に解明することは円錐円筒ソケット接合よりもはるかに困難と言える。そこで, 本論では, 実験結果の解説に重点を置き, 解析的検討については次の機会に譲 ることとした。

\section{2. 実験の計画}

\section{1 試験体の構成と形状}

試験体は図 2 に示すように，角筒，角錐，蓋板から成り，一部， 角リング（角筒上縁の補強材）が付属する場合がある。これらの形 状，寸法，材質は，今回の試験体（合計13体）すべて同一で，図に 示した通りである。角筒は一般構造用角形鋼管（ $\square-125 \times 4.5$, STKR400）である。角錐は一般構造用圧延鋼材（鋼板厚さ4.5, SS400）をプレス曲げし，2つを合わせて平板部中央で溶接したも のである（外面は角形鋼管と接触するので溶接の余盛をグライン ダーで切削した)。ただし，一部，特殊な細工を施した試験体があ る。先ず，3 体の試験体（No.7，8，9）については角錐の稜線部 のみを残し平板部に台形状の空を明けた。これは，角錐の耐荷機構 における稜線部と平板部の寄与を調べるためのもので，実用上のも のではない。開口の寸法を図 3 に示す。また，摩擦の影響を調べる ために，試験体 No.13については角筒上縁の内側にアール仕上げを し，試験体 No.10については角錐と蓋板の間にテフロン板を挟ん だ。その形状を図 3 に示す。試験体に用いた鋼材の力学的性質を表 1 に示す。

この接合部を構成する個々の部品の形状, 寸法, 材質（例えば, 角錐の頂角, 板の厚さ, 材料の強度など), 及びその組み合わせ方は, この接合部の力学的性能に多かれ少なかれ影響を与えるはずであ る。しかし，その全貌がつかめていないので，今回設定した試験体 条件の位置付けや最適となるであろう標準仕様は現段階では提示で きないことを断っておきたい。角形閉断面材の接合形式として考案 されたソケット接合が 1 ケースの試験体条件においてでも構造力学 的に有効であることが例証されれば，今後の発展が期待できるもの となるであろう。

\section{2 試験変数}

試験体（13体）のリストを表 2 に示す。それぞれの試験体は次の ような違いを与えており，その影響を見るのが本論の目的となる。

No. 1 : 角筒と角錐の溶接，角錐と蓋板の溶接，および補強リン グのいずれも無い基準試験体（全面一様圧縮）

No. 2 : 角筒と角錐を溶接（全面一様圧縮）

No. 3 : 角錐と蓋板を溶接（全面一様圧縮）

No. 4 : 角筒と角錐，および角錐と蓋板を溶接（全面一様圧縮）

No. 5 ：補強リングを装着（全面一様圧縮）

No. 6 ：補強リングを装着し，角錐と蓋板を溶接(全面一様圧縮)

No. 7 ：No. 1仕様で角錐平板部に大きな空明け（全面一様圧縮）

No. 8 ：No.1仕様で角錐平板部に小さな空明け（全面一様圧縮）

No. 9 ：No.6仕様で角錐平板部に大きな空明け（全面一様圧縮）

No. 10 ：No. 1仕様で角錐と蓋板の間にテフロン板(全面一様圧縮）

No. 11：No. 4仕様（対角線局部圧縮）

No. 12 : No. 4仕様（辺中央局部圧縮）

No. 13 ：No. 3仕様で角筒上縁アール仕上げ（全面一様圧縮）

上記のうち，No.11，No.12のみが局部圧縮となっている。これ

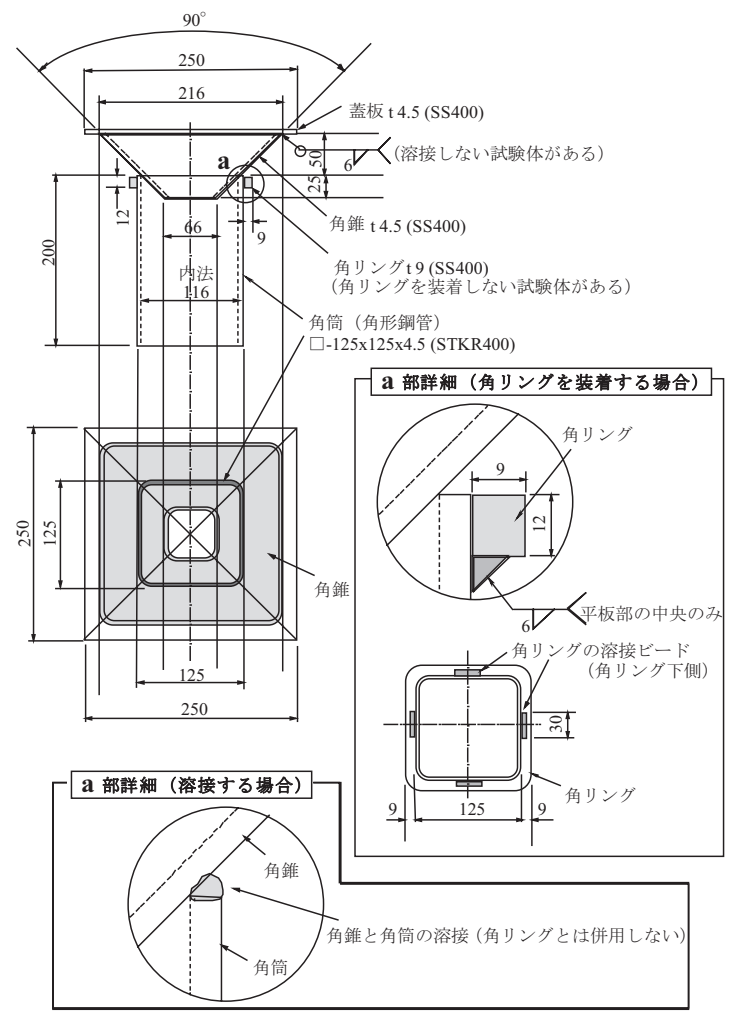

図2 試験体の構成

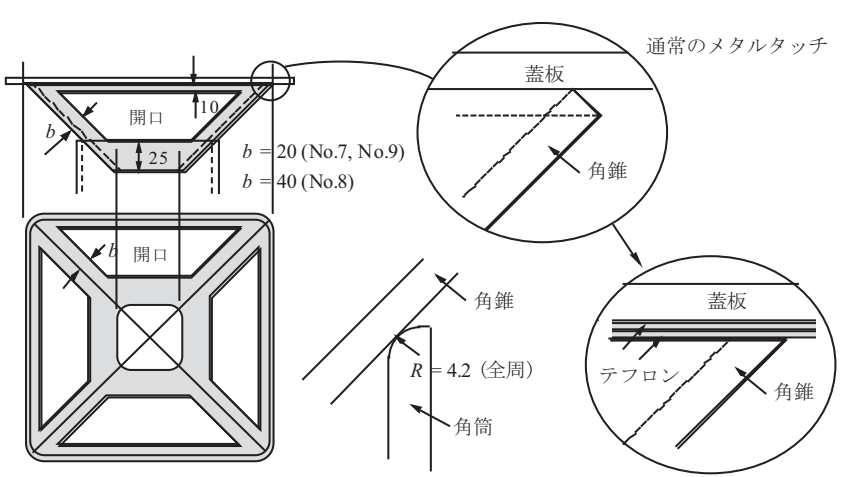

（1）角錐壁面の開口（2）角筒上縁のアール仕上げ（3）テフロン板挿入の場合 図3 角錐壁面の開口，角筒上縁のアール仕上げ，およびテフロン板挿入

表 1 鋼材の引張試験結果

\begin{tabular}{|c|c|c|c|c|c|}
\hline 鋼種 & $\begin{array}{c}\text { 実測板厚 } \\
(\mathrm{mm})\end{array}$ & $\begin{array}{c}\text { 降伏強さ } \\
\left(\mathrm{N} / \mathrm{mm}^{2}\right.\end{array}$ & $\begin{array}{c}\text { 引張強さ } \\
\left(\mathrm{N} / \mathrm{mm}^{2}\right)\end{array}$ & $\begin{array}{c}\text { 一様伸び } \\
(\%)\end{array}$ & 備考 \\
\hline SS400 & 4.2 & 348 & 433 & 17 & 角錐, 蓋板 \\
\hline SS400 & 8.6 & 312 & 439 & 19 & 角リング \\
\hline STKR400 & 4.2 & 378 & 454 & 17 & 角筒 \\
\hline
\end{tabular}

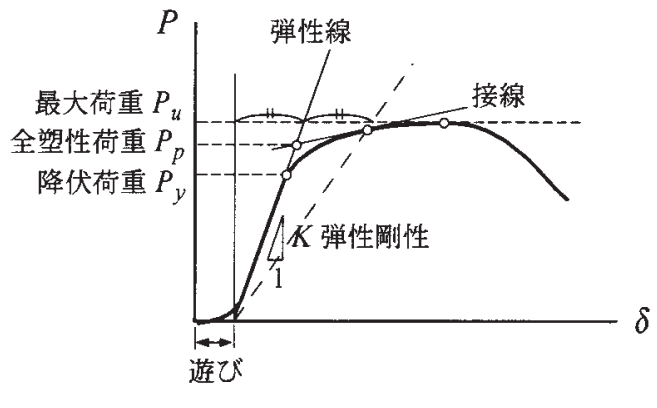

図４耐力と剛性の定義 
表 2 角錐-角筒ソケット接合試験体の実験条件と実験結果

\begin{tabular}{|c|c|c|c|c|c|c|c|c|c|c|c|}
\hline 試験体 & & & 実験条件 & & & & & 実験結果 & & & \\
\hline No. & $\begin{array}{c}\text { 角錐と角筒 } \\
\text { の溶接 } \\
\end{array}$ & $\begin{array}{c}\text { 角錐と蓋板 } \\
\text { の溶接 } \\
\end{array}$ & $\begin{array}{l}\text { 角リング } \\
\text { の装着 }\end{array}$ & 特殊条件 & 載荷 & 崩壎モード & $\begin{array}{c}\text { 降优荷重 } \\
{[\mathrm{kNN}]}\end{array}$ & $\begin{array}{c}\text { 全塑性荷重 } \\
\text { [kN] }\end{array}$ & $\begin{array}{c}\text { 最大荷重 } \\
\text { [kN] }\end{array}$ & $\begin{array}{l}\text { 弾性剛性 } \\
{[\mathrm{kN} / \mathrm{mm} \text { ] }}\end{array}$ & $\begin{array}{l}\text { 遊び } \\
{[\mathrm{mm}]}\end{array}$ \\
\hline 1 & $\times$ & $\times$ & $x$ & - & 全面 & $\begin{array}{c}\text { 角錐稜線曲|゙崩壊 } \\
\rightarrow \text { 角錐上縁すべり崩墺 }\end{array}$ & 149 & 236 & 283 & 54 & 1.2 \\
\hline 2 & 0 & $\times$ & $\times$ & - & 全面 & 角錐上縁すベり崩㙞 & 200 & 333 & 346 & 133 & 0.4 \\
\hline 3 & $\times$ & 0 & $x$ & - & 全面 & 角錐棱線曲|゙゙崩壊 & 158 & 251 & 319 & 58 & 0.3 \\
\hline 4 & 0 & 0 & $\times$ & - & 全面 & 角雓掕線曲|f゙崩壊 & 273 & 359 & 386 & 325 & 0.3 \\
\hline 5 & $\times$ & $\times$ & 0 & - & 全面 & $\begin{array}{c}\text { 角錐稜線曲|゙崩壊 } \\
\rightarrow \text { 角錐上縁すべり崩墺 }\end{array}$ & 174 & 228 & 308 & 76 & 0.5 \\
\hline 6 & $\times$ & 0 & 0 & - & 全面 & 角錐棱線曲|゙゙崩壊 & 188 & 238 & 346 & 83 & 0.3 \\
\hline 7 & $\times$ & $\times$ & $\times$ & \begin{tabular}{|c|} 
角錐空明志 \\
稜線部幅19.5 \\
\end{tabular} & 全面 & 角錐稜線曲|゙崩壊 & 57 & 78 & 81 & 34 & 0.6 \\
\hline 8 & $\times$ & $x$ & $x$ & \begin{tabular}{|c|} 
角雓空明志 \\
棬線部幅36.8 \\
\end{tabular} & 全面 & $\begin{array}{c}\text { 角錐稜線曲|゙崩壊 } \\
\rightarrow \text { 角錐上縁すべリ崩墺 }\end{array}$ & 110 & 165 & 180 & 43 & 0.3 \\
\hline 9 & $\times$ & 0 & 0 & \begin{tabular}{|c|} 
角雓密明志 \\
稜線部幅20.4 \\
\end{tabular} & 全面 & 角錐稜線曲|゙崩壊 & 62 & 84 & 90 & 48 & 0.1 \\
\hline 10 & $\times$ & $\times$ & $\times$ & $\begin{array}{l}\text { 角錐と蓋板に } \\
\text { テフロ捚入 }\end{array}$ & 全面 & 角錐上縁すべり崩坥 & 80 & 101 & 110 & 43 & 0.3 \\
\hline 11 & 0 & 0 & $\times$ & - & $\begin{array}{c}\text { 局部 } \\
\text { (対角線) }\end{array}$ & 蓋板一角錐棸曲げ崩壊 & 92 & 137 & 167 & 56 & 0.2 \\
\hline 12 & 0 & 0 & $\times$ & - & $\begin{array}{c}\text { 局部 } \\
\text { (辺中央) }\end{array}$ & 蓋板一角錐系曲げ崩塭 & 170 & 212 & 215 & 116 & 0.3 \\
\hline 13 & $\times$ & 0 & $\times$ & $\begin{array}{l}\text { 角筒縁の } \\
\text { アール加工 }\end{array}$ & 全面 & 角筒縁角部舌状崩墺 & 87 & 97 & 262 & 100 & 0.5 \\
\hline
\end{tabular}
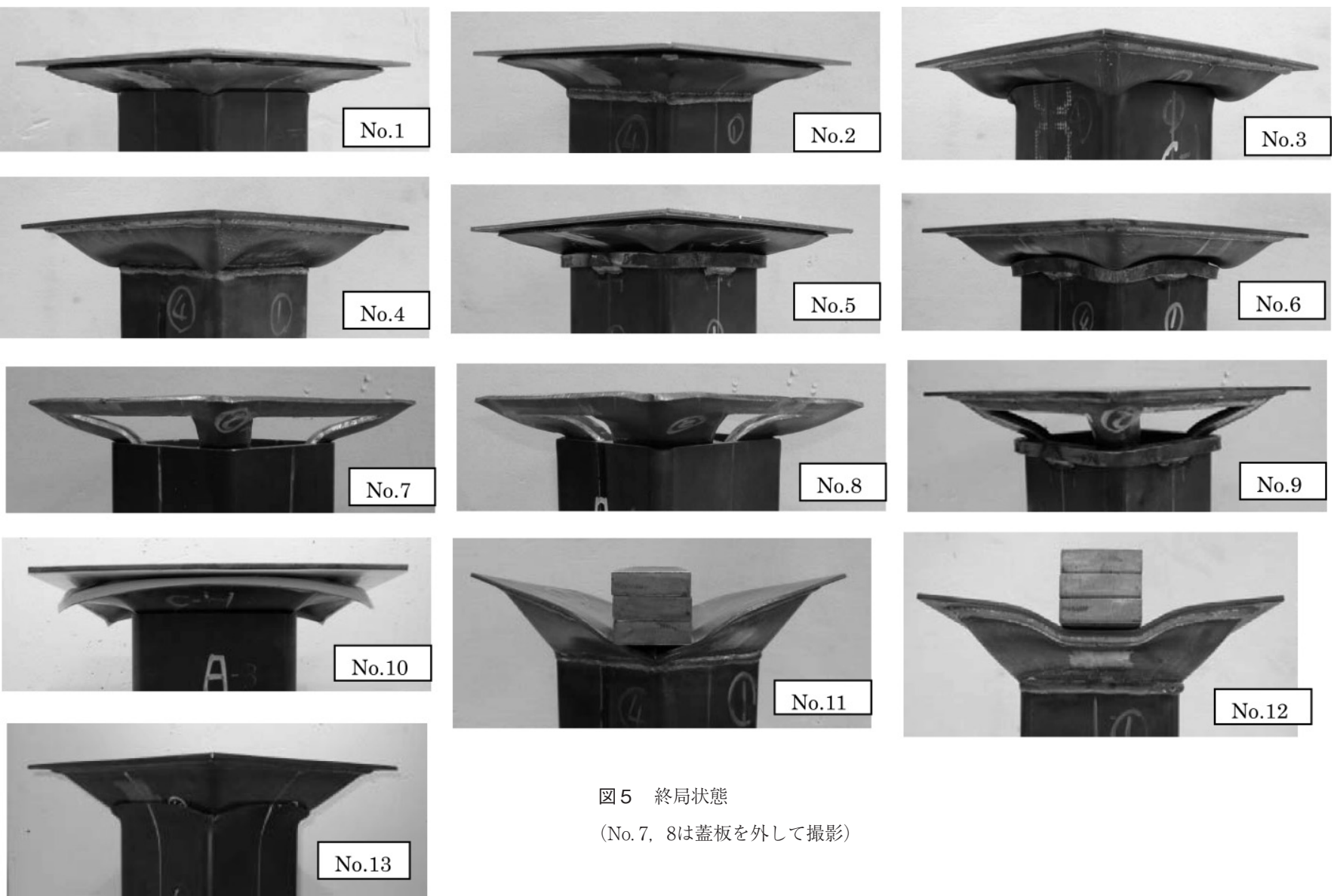

図 5 終局状態

(No.7，8は蓋板を外して撮影)

は図 1 の構法例(a)において, 梁フランジ幅が蓋板の中央に帯状に載 る場合に該当するが，ここでは，耐力発現の様子を探るために設定 した載荷条件でもある。

\section{3 載荷および計測}

加力は準静的な単調圧縮載荷とした。全面一様圧縮の場合は蓋板 の全面にピストンヘッドに装着した剛な載荷盤が当たるように載荷 した。局部圧縮の場合は，載荷盤と蓋板の間に細長い鋼板（幅 


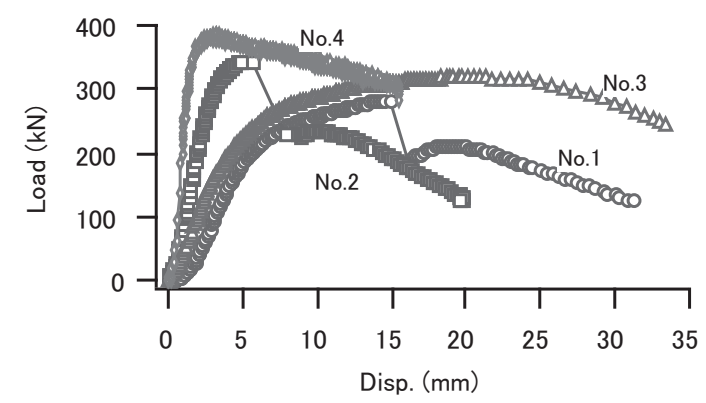

(1) 溶接の影響

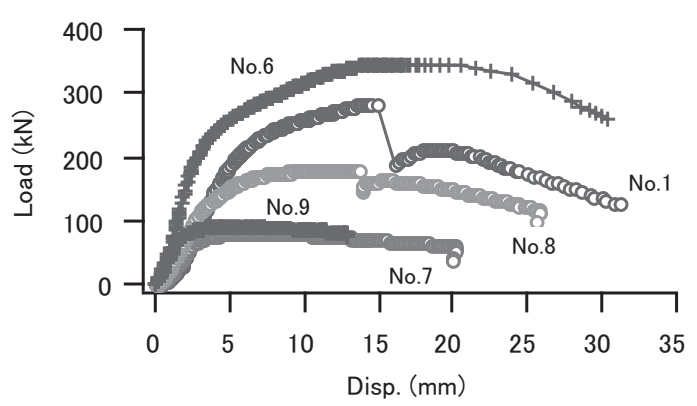

（3）角錐開口の影響

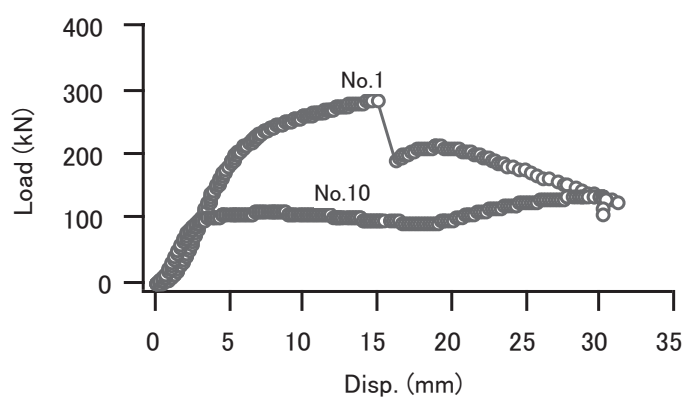

(5) 角錐-蓋板間の摩擦の影響

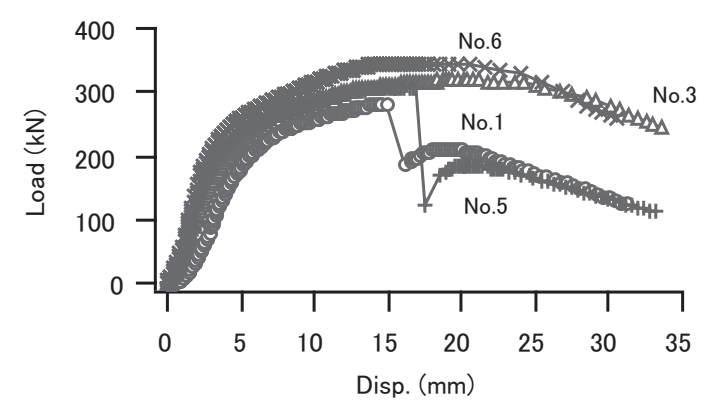

（2）補強リングの影響

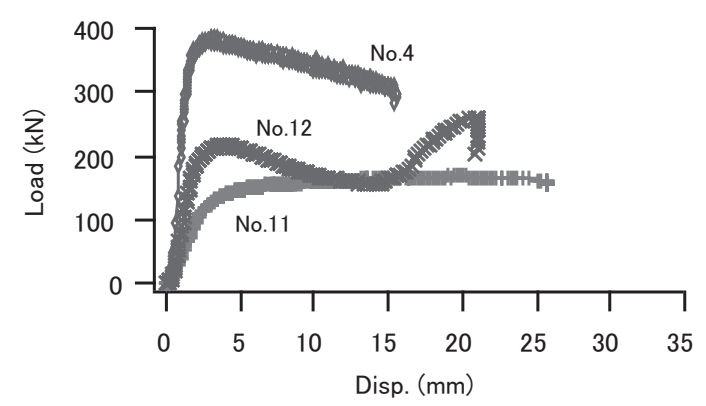

（4）局部載荷の影響

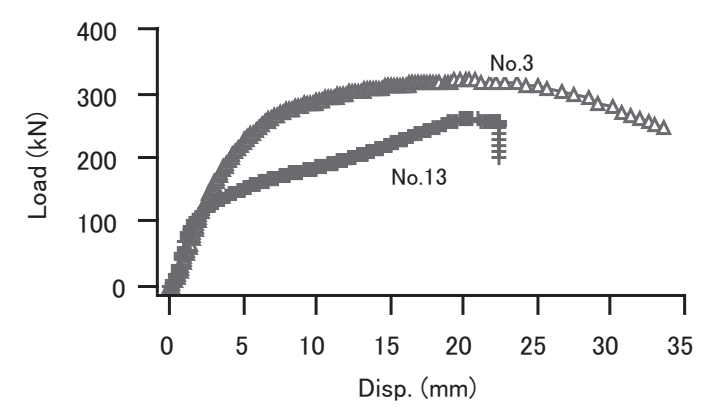

(6) 角錐-角筒間の摩擦の影響

図6 荷重-変形曲線

45mm）を角錐の対角線あるいは辺中央に挟んで載荷した。計測項 目は，ピストンに装着したロードセルによる荷重，および試験体の 周辺に対称配置したレーザー変位計 4 本による角筒下面から上部載 荷盤までの縮み量である。

\section{3. 実験結果}

\section{1 耐力および剛性}

荷重-変形曲線は今回の試験体に共通して図 4 のように表示する ことができる。降伏荷重, 全塑性荷重, 最大荷重, 弾性剛性, 遊び は，図に示す通りである。荷重が変形に比例して上昇する直線部分 を弾性線とし, その勾配を弾性剛性とした。荷重一変形曲線がこの 弾性線から外れ始める点の荷重を降伏荷重とした。また, 弾性線が 横軸と交わる点を遊びの終点とし，その変形を遊びとした。遊びの 終点から弾性剛性の $1 / 2$ の勾配で引いた直線が荷重-変形曲線と交 差する点で接線を引き,それが弾性線と交わる点の縦座標を便宜上, 全塑性荷重とした。これらのデータを前出表 2 の実験結果の欄に整 理しておいた。

今回の実験で，遊びは $0.1 \sim 1.2 \mathrm{~mm}$ の範囲にある。遊びは，この 接合部を構成する部品間の初期接触状態に依存すると考えられ, 接
触周を溶接したものは遊びが小さくなっている。弾性剛性は, 特別 な細工をしていない試験体 No. 1〜No. 6に限っても， $54 ３ 25 \mathrm{kN} /$ $\mathrm{mm}$ の広範囲にわたっている。これは, 角錐の上縁及び下縁接触周 の変形拘束の影響が大きいからであり, メタルタッチのままよりも 溶接を施したほうが剛性が高くなる。角錐の上下縁とも溶接した試 験体 No. 4は最大の弾性剛性 $325 \mathrm{kN} / \mathrm{mm}$ を記録しているが, これは 今回用いた角形鋼管のみが $1.3 \mathrm{~m}$ 長のときの軸剛性に相当する值で ある。耐力については崩壊モードとあわせて後で考察する。

\section{2 終局状態}

すべての試験体の終局状態を示す写真を図 5 に掲載する。それら を分類すると，次のようになる。

角錐上縁のすべりを伴う不安定崩壊：No. 1，2，5，8

角錐上縁のすべりを伴う緩やかな崩壊：No. 10

角錐稜線の曲げ崩壊：No. $3,4,6,7,9$

角筒上縁角部の舌状局部崩壊 : No. 13

蓋板-角錐系の曲げ崩壊：No. 11, 12

\section{3 荷重-変形曲線}

荷重-変形曲線を図 6 に掲載する。荷重は試験機から加えられる 圧縮力である。変形は角筒-角錐-蓋板系の全高さの変化量 (沈下量) 
で, 対称配置した 4 本の変位計の值の平均值である。図 6 は荷重一 変形曲線を 6 つに分類してある。(1)はメタルタッチに対する溶接の 影響, (2)は補強リング装着の影響, (3)は角錐の壁面（ウェブ）に明 けた開口の影響，(4)は全面一様圧縮に対する局部載荷の影響，(5)は 角錐と蓋板の間にテフロン板を扱入することによる摩擦低減の影 響，(6)は角筒縁にアール仕上げをすることによる角錐一角筒間の摩 擦低減の影響を見たものである。

\section{4. 実験結果の考察}

\section{1 摩擦について}

今回の角錐-角筒ソケット接合の圧縮実験で特筆すべき事項の一 つは摩擦の影響である。摩擦が関与するのは, 角錐と角筒の接触部 及び角錐と蓋板の接触部の 2 ケ所である。

先ず，角錐が角筒とメタルタッチするケースについて，角筒縁に リング補強抒よび仕上げのない試験体 No.1とNo.3を見ると（図 5 ), 角筒縁はその角部が外に向かって舌状変形を起こすだけで, 角錐は角筒の中へ沈降して行かない（No.7，8，10も同様）。これ は同厚の円錐-円筒ソケットで円錐が円筒縁を押し拡げながら円筒 内に沈降していった現象 ${ }^{1)}$ と全く異なる様相である。No.3の角筒角 部とそこに接触する角錐稜線部の試験後の状況を図 7 に示す。角筒 角部は舌状の降伏変形を起こしているが平板部へは降伏が拡がって いない。角錐稜線には角筒角部の尖った内側縁が食い込んだ爪状の 痕跡が残っている。すなわち, 角錐稜線と角筒の接触部には非常に 大きな摩擦力が生じ, これによって角錐は角筒内部にほとんど沈み 込まなかったと推定される。このため, 角筒縁をリング補強しても 最大荷重はほとんど増加しなかった（No.1の $283 \mathrm{kN}$ に対して No. 5 の $308 \mathrm{kN}$ ，およびNo. 3の $319 \mathrm{kN}$ に対してNo.6の346kN，図 6(2))。 これに対して角筒上縁の内側にアール仕上げ（前出図 3 ）を施した No.13では, このような食い込みによる摩擦が生じなかったため, 角錐は角筒縁を押し拡げながら沈降して行き，最終的に角筒角部が フープ応力で引張破壊した（図 5 )。その最大荷重 $262 \mathrm{kN}$ は, 他が 同条件の No.3の $319 \mathrm{kN}$ よりさく, 摩擦力の違いが崩壊モードの 違いをもたらし，最大荷重にも影響を与えている（図 6(6))。

次に，角錐が蓋板とメタルタッチするケースについて，試験体 No. 1, No. 2, No. 5の最終状況の写真を見ると, 角錐上縁が拡幅し, 角錐が扁平化している様子がわかる。さらに, これらの荷重-変形 曲線を見ると, 最大荷重点で急激な荷重低下を起こしており, その 間はデータが採取できていない。試験後の蓋板を観察すると, 図 8 に示すように，角錐が接触していたライン上に圧力痕とすべり痕が ある。このことから，角錐上縁の尖った内縁が蓋板にめり込むこと によって相当大きな摩擦力が作用し，最終的にこれがすべって急激 な扁平化崩壊を引き起こしたものと推定される。このような現象は 円錐一円筒ソケット接合では見られなかったものである11。一方, 角錐と蓋板の間にテフロン板を挟んだ試験体 No.10では, 角錐上縁 が緩やかに拡がっていき，急激なすべり崩壊は起きなかった（図 5 ， 図 $6(5))$ 。その最大荷重 $110 \mathrm{kN}$ は同条件の No. 1 の $283 \mathrm{kN}$ より相当 小さく，摩擦の影響が耐力に大きな影響を与えている。ただ，後述 のように角錐は蓋板と溶接して 1 個の部品として用いるほうが便利 であるので, このことは実用上の課題とはならないであろう。
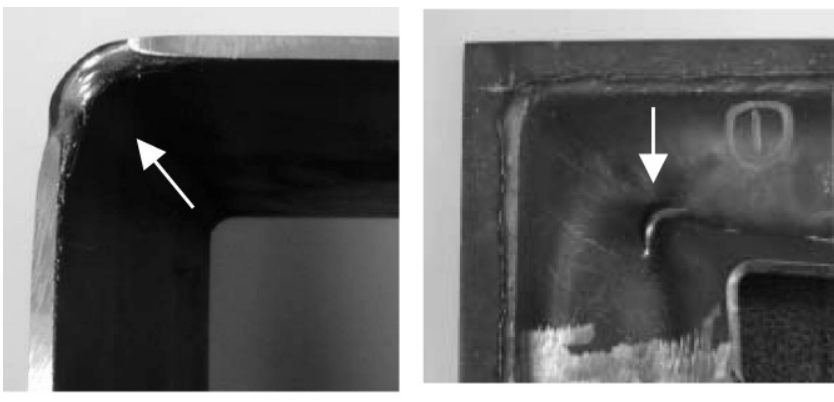

図 7 角筒角部と角錐棱線の損傷状況（No. 3）

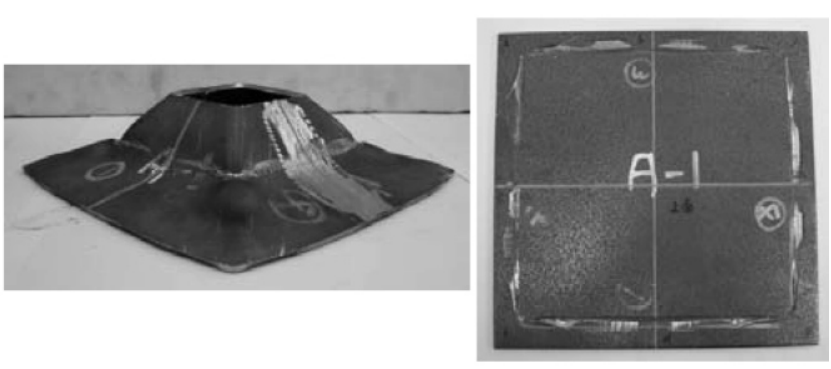

図８角錐の扁平化と蓋板のすべり痕（No. 1）

\section{2 稜線部と平板部の荷重分担について}

曲げを受ける折板構造は, 剛性の高い稜線部（稜線とその両側の 平板部から成る山形断面部分）が主として荷重を負担し，面外剛性 の小さい平板部は補助的な役割をすると考えられている。今回，そ れについて調べたのが試験体 No. 7，8，9で, 角錐の平板部に台形 の空（開口）を明けたものである（前出図 3 )。No.7は開口が大き く, 残存する稜線部の片側幅が $20 \mathrm{~mm}$ (実測19.5), No. 8は開口が 小さく片側幅が $40 \mathrm{~mm}$ (実測36.8）である。これらを同条件で開口 のない試験体 No. 1 と最大荷重で比較すると, No. 1が $283 \mathrm{kN}$ に対し てNo. 7は $81 \mathrm{kN}$, No. 8 は $180 \mathrm{kN}$ となっており, 耐力が激減してい る（図 6(3))。同様に, 蓋板との溶接および角リング補強がある場 合に大きな開口を明けたNo.9を同条件で開口のないNo.6と比較 すると, 最大荷重は $346 \mathrm{kN}$ から $90 \mathrm{kN}$ に激減している。これは降伏 荷重についても同様である。以上のことから, 角錐の圧縮耐力に対 して平板部の補助的役割は非常に大きく, 稜線部だけで耐荷機構を 考えることは無理があると言える。例えば, 常套手段としてよく用 いられる有効幅の概念を導入して, 稜線部を等価な山形断面をもつ アングル材に置換して耐力を推定することは, 便法としてはあり得 ても，実現象には適合しないことを空明き角錐の実験結果が暗示し ている5゙。平板部はたとえ圧縮力を負担する割合いが小さいとして も，稜線部が曲げによって扁平化する現象（これはアングルの屈 伏 ${ }^{12)}$ として知られている) を拘束するなど重要な役割を担っている と考えなければならない。

\section{3 局部載荷について}

局部的な圧縮載荷の影響を調べた 2 体の試験結果について考察す る。試験体 No. 11は角錐の対角線上すなわち相対する稜線の直上に 局部載荷したもので (以下, 対角線載荷), No. 12 は角錐の平板部 中央すなわち稜線から最も離れた位置に局部載荷したものである (以下，辺中央載荷)。これらの耐力と剛性は, 当然, 同条件で全面 載荷したNo.4より小さい（図6(4))。しかし, 予想に反して, 対角 
線載荷よりも辺中央載荷のほうが, 降伏耐力, 最大耐力, 弾性剛性 のいずれにおいても大きい值を示す。図 5 に示したNo. 11, No. 12 の終局状態を観察すると,いずれも角錐が面外変形を起こしている。 面外変形に対して平板部のほうが稜線部よりも軟弱なはずであるに もかかわらず, 辺中央載荷のほうが対角線載荷より剛強という実験 結果である。今のところ，この実験結果を説明できる理論はなさそ うである。

\section{4 実用化について}

以上見てきたように，この接合形式の力学挙動は構成部品間の接 触部がメタルタッチか溶接かによって相当異なってくるので, 実用 面ではその選択が重要となる。冒頭図 1 の構法例(a), (b), (c)を想定 すると, 先ず，蓋板は，ベースプレートあるいは他との接合要素と して機能するので, 予め角錐と溶接しておくことになると思われる。 また，そうしておくことによって，4.1で述べた角錐縁のすべりに よる急激な扁平化崩壊の危険を回避できる。一方，角錐と角筒の継 目をメタルタッチのままとするか，溶接するかは設計意図によると 思われる。円錐と円筒の場合は, メタルタッチとしておくことによ り全方向ピンとして扱えることが実験で確認されているが2), 角錐 と角筒の場合は，上で見たように摩擦係数が大きいこと，および幾 何学的に滑らかな回転運動が困難であることが予想されるので，今 後, 実験的な調査が必要である。

以下，角錐を蓋板㧍よび角筒に両方とも溶接した場合について， 耐力と剛性に関する実用上の課題を検討してみる。先ず，今回の実 験に扮ける角形鋼管の降伏軸力は, 公称值で降伏応力 $\times$ 断面積 $=$ $235 \mathrm{MPa} \times 2117 \mathrm{~mm}^{2}=500 \mathrm{kN}$ である。これに対して，角錐-角筒ソ ケット接合の最大耐力は $386 \mathrm{kN}$ である(試験体 No.4)。したがって, 保有耐力接合の条件を満たすには，角錐を角筒の板厚より大きくし ておくか，あるいは高強度の鋼材を用いる必要がある。仮に，角錐 の耐力が曲げで決定されているとすると，今回の角筒の厚さ $4.5 \mathrm{~mm}$ に対して, 角錐の厚さは, 面外曲げ支配のときその $\sqrt{500 / 386}$ 倍す なわち $5.1 \mathrm{~mm}$ 以上，面内曲げ支配のときその500/386倍すなわち $5.8 \mathrm{~mm}$ 以上, とする必要がある。これは, 実用上対応可能な数值 である。ただし，角錐の耐荷機構が明らかでないので，その合理的 計算方法については今後の研究を待つ必要がある。

次に, 試験体 No. 4の実験結果から, このソケット接合が降伏に いたるときの変形は $1 \mathrm{~mm}$ 未満, 載荷初期に見られる遊びは $0.3 \mathrm{~mm}$ と非常に小さい。このことから，剛性については実用上，問題はな いであろうと考えられる。

このソケット接合の引張，および曲げに対する性能はまだ明らか にされておらず，今後の課題である。このとき，角錐と角筒の溶接 継目（前出図３）は，完全溶込み溶接と見なせるに足る強度を発揮 できるかどうかなども併せて検討する必要がある。

本稿で検討したソケット接合の原型はレジューサ（reducer）で ある。これは，配管工事において径の異なる2つの管（通常は円形 鋼管）を継ぐときに用いられるテーパー付きの管である。これに類 似したものとして, 径の異なる鋼管の柱を継ぐ際の構造用レジュー サがある。いずれの場合も，レジューサの両端はそれぞれの鋼管に 突合せ溶接される。このようなレジューサ継手に対して, ソケット 接合の特徵は突合せ溶接をしないところにあると言える（図 1 参 照)。今回の試験体のうち, 角形断面柱の構造用レジューサに近い
のは溶接を施した試験体 No.4の角錐である。既に見たように, こ の角錐は圧縮荷重によって稜線部の曲げ崩壊を起こしている。この ような崩壊形式は柱のレジューサ継手の設計では頂角が比較的小さ いこともあり想定されていない。角錐の崩壊形式や耐力には頂角の 大きさが関与するであろうから (今回は 90 度のみ), その影響も含 めた検討が必要であろう。

\section{5. まとめ}

鋼板を成形加工した角錐を角形鋼管にはめ込んだ角錐一角筒ソ ケット接合の圧縮試験を行い, その性能について次の結果が得られ た。

1 ）角錐と蓋板を溶接なしのメタルタッチとしたとき, 両者の線接 触部の摩擦が切れる瞬間, 角錐の裾部分が扁平化し, 急激な荷重 低下を示した。両者の間にテフロン板を挿入して摩擦係数を意図 的に低減すると，角錐の裾部分は緩やかに扁平化し崩壊した。

2 ）角錐と角筒を溶接なしのメタルタッチとしたとき, 角筒角部に 局所的な降伏が生じるが，大きな摩擦力が維持され，最終的には 角錐が曲げ崩壊した。そのため, 角筒上縁を角リングで補強する 効果は小さかった。しかし, 角筒縁にアール仕上げを施して意図 的に摩擦係数を低減すると角錐が角筒内部に沈降し角筒角部が フープ応力で破壊した。

3）角錐と蓋板，および角錐と角筒を全周溶接することにより，実 用上必要な剛性と耐力が得られることが判明した。

4) 角錐平板部に開口を明けると耐力が著しく低下する。角錐稜線 の耐荷能力に対する平板部の補助効果は大きいと考えられる。

5 ) 局部圧縮では, 一様な全体圧縮に比べ, 剛性と耐力が低下す る。このとき, 角錐の対角線載荷のほうが辺中央載荷よりも厳し い載荷条件となる。

本論では，角錐一角筒ソケット接合の圧縮性能について実験結果 とその定性的解釈のみを示した。耐荷機構および剛性・耐力の理論 的検討については今後の研究に委ねることとする。

\section{謝辞}

角錐一角筒ソケット接合の実験において江原勇介君（元東京大学 大学院生）の協力を得た。

\section{参考文献}

1）桑村 仁, 伊藤拓海, 富岡裕一：鋼製円錐一円筒ソケット接合の研究, 日 本建築学会構造系論文集, No. 598, pp.155-162, 2005.12.

2）桑村 仁，伊藤拓海：鋼製円錐-円筒ソケット接合の摩擦による回転抵抗 一鋼製円錐一円筒ソケット接合の研究 その 2 -, 日本建築学会構造系論 文集，No.622，pp.169-176，2007.12.

3）伊藤拓海, 江原勇介, 桑村 仁：圧縮力を受ける鋼製円錐一円筒ソケット 接合の円筒縁崩壊－鋼製円錐一円筒ソケット接合の研究 その 3 -, 日本 建築学会構造系論文集, No. 630, pp.1377-1384, 2008.8.

4）桑村 仁, 伊藤拓海, 江原勇介 : 角形鋼管に角錐をはめ込んだ接合構法 に関する研究（その 1 成立性評価試験の概要）（その 2 角錐の曲げ崩 壊と座屈崩壊）(その 3 角錐の最大耐力に関わる稜線部の有効幅), 日 本建築学会大会学術講演梗概集, pp.631-636, 2006.9.

5）江原勇介，伊藤拓海，桑村 仁：角形鋼管に角錐をはめ込んだ接合構法 に関する研究（その 4 平板部を除去した角錐）（その 5 テフロンシー 卜を挿入した角錐）（その 6 局部載荷を行った角錐）、日本建築学会関 東支部研究報告集 I, pp.121-132, 2007.3.

6）江原勇介，伊藤拓海，桑村 仁：角形鋼管に角錐をはめ込んだ接合構 
法に関する研究（その 7 角筒縁崩壊）（その 8 線材置換モデルによる 角錐の降伏耐力と弾性剛性), 日本建築学会関東支部研究報告集 I, pp.261-268, 2008.2.

7) Flugge, W.: Stresses in Shells (Sections 3.5, 5.7), $2^{\text {nd }}$ ed., Springer-Verlag, 1973.

8）望月 重, 谷 資信ほか：板構造（第 4 章 折板）, 鹿島出版会, 1976.4.

9）谷 資信：建築物の構造解析シリーズ 3 板構造の解析, 技報堂出版, 1976.8.

10）田中彌壽夫ほか：新建築学体系37 板構造の解析（第 6 章 折板の解 析), 彰国社, 1989.11.

11）榎並 昭：折板構造の破壊に関する研究（その 7 ）, 日本建築学会論文報 告集, No.67, pp.28-34, 1961.2.

12）桑村 仁：アングルの屈伏，日本建築学会構造系論文集，No. 629 , pp.1169-1175, 2008.7.

(2008年10月 7 日原稿受理，2009年 1 月15日採用決定） 